Bond University

Research Repository

\title{
Validity, utility and ethics of profiling for serial violent and sexual offenders
}

Wilson, Paul; Lincoln, Robyn; Kocsis, Richard

Published in:

Psychiatry, Psychology and Law

DOI:

10.1080/13218719709524891

Licence:

Other

Link to output in Bond University research repository.

Recommended citation(APA):

Wilson, P., Lincoln, R., \& Kocsis, R. (1997). Validity, utility and ethics of profiling for serial violent and sexual offenders. Psychiatry, Psychology and Law, 4(1), 1-11. https://doi.org/10.1080/13218719709524891

\footnotetext{
General rights

Copyright and moral rights for the publications made accessible in the public portal are retained by the authors and/or other copyright owners and it is a condition of accessing publications that users recognise and abide by the legal requirements associated with these rights.
}

For more information, or if you believe that this document breaches copyright, please contact the Bond University research repository coordinator. 


\title{
Validity, Utility and Ethics of Profiling for Serial Violent and Sexual Offenders
}

\author{
Paul Wilson \\ School of Humanities and Social Sciences, Bond University, Gold Coast \\ Robyn Lincoln \\ School of Humanities and Social Sciences, Bond University, Gold Coast \\ Richard Kocsis \\ Department of Psychology, University of New England,Armidale
}

\begin{abstract}
$\mathrm{D}$ espite its apparent popularity, criminal personality profiling has been poorly evaluated as either an investigative aid or a conceptual tool. This article documents some aspects of the development of offender profiling. Importantly, it identifies and differentiates the different styles of profiling and their distinct conceptual orientations. The literature is also reviewed to extract what conclusions can be drawn with respect to the validity, utility and ethics of offender profiles in criminal investigations and what this may mean for psychiatry, psychology and the law in general.
\end{abstract}

The investigative technique, variously referred to as offender profiling, psychological profiling, criminal investigative analysis, and other nomenclatUres, has gained in prominence in recent years. Most of the overviews of profiling suggest that its current ascendancy is due in large part to exposure in popular media rather than through positive empirical results (Davies 1994; Smith 1993; McCann 1992). Therein lies the problem

- that criminal personality profiling has been poorly evaluated as either an investigative aid or a conceptual tool.

Profiling has been described as 'a collection of leads' (Rossi 1982) or as a 'biological sketch of behavioral patterns, trends, and tendencies' (Vorpagel1982). It is based on the premise that anyone who enters a crime scene takes something of the scene with them and leaves something of themselves behind (Davis 1994). So what can be recovered at a crime scene, utilising vari'ous psychological, criminological and sociological principles applied to the physical evidence, is intended to give an impression of the person who committed the offence (Douglas \& Munn 1992; Burgess, Hartman, Ressler, Douglas \& McCormack 1986; Ressler, Burgess, Douglas, Hartman \& D'Agostino 1986; Turco 1990).

This paper is a revised version of that presented at the 16th Annual Congress of the Australian and New Zealand Association of Psychiatry, Psychology and Law, Surfers Paradise, August 1996.

Correspondence to: Professor Paul Wilson, Dean of Humanities and Social Sciences, Bond University, Gold Coast QLD 4229, Australia. 
While personality profiling is said to be applicable to conventional forms of crime (Slahor 1991), it has been found to be particularly useful when the unknown offender demonstrates some form of psychopathology (Geberth 1981). And it is when conventional investigative methods have failed that profiling appears most beneficial (Fleming 1994). This often occurs when motives - traditionally used by law enforcement to make deductions about perpetrators - are less evident (Fisher 1993; Walter 1987). However, the technique should not be exclusively reserved for bizarre and seemingly motiveless crimes.

What should be said at the outset is that criminal personality profiles certainly do not solve crimes, as is often a mistaken popular belief (Ressler \& Schactman 1992; Nowikowski 1995). They are merely an investigative tool or resource which can be utilised by law enforcement personnel (Vandiver 1982; Jeffers 1992). To date, the literature shows that profiles have been found to be most effective as an additional tool, not as a solution to specific crimes (Jackson, Van Hoppen \& Hebrink 1993; Pinizzotto 1984).

However, profiling has now branched out into new areas, including derivatives such as proactive investigative strategies (Douglas \& o lshaker 1996), coordinated interview and interrogation techniques (Holmes 1989) and appraisal of equivocal deaths (Hazelwood, Dietz $\&$ Burgess 1982). Some of these processes have very similar features under different names, but others are developments of the original crime scene analysis techniques. In addition, there are significant developments in the use of computerised databases and analytical software such as VICAP and PROFILER in the United States, and the Violent Criminal Linkage Analysis System (ViCLAS) used by the Australian Violent Crime Analysis Centre (AVCAC) which began operation in 1996 (see Rayment 1995).

Having noted some general observations about the group of techniques called profiling, what is most apparent is that the strengths and weaknessess of offender profiling have been assessed for far too long by anecdotal success stories serendipitously disclosed by law enforcement agencies,. or from sensationalised failures often distorted by the mass media. This paper therefore attempts to assess offender profiling from its origins in psychiatry to a new sub-discipline within the behavioural sciences. Importantly, it identifies and differentiates the different styles of profiling and their distinct conceptual orientations (see Table 1). The literature is also reviewed to extract what conclusions can be drawn with respect to the validity, utility and ethics of offender profiles in criminal investigations and what this may mean for psychiatry, psychology and the law in general.

Table I

Proponents and methods for the three different approaches to profiling.

\begin{tabular}{|c|c|c|c|}
\hline & $\begin{array}{l}\text { DIAGNOSTIC } \\
\text { EVALUATIONS }\end{array}$ & $\begin{array}{c}\text { CRIMESCENE } \\
\text { ANALYSIS } \\
\end{array}$ & $\begin{array}{l}\text { INVESTIGATIVE } \\
\text { PSYCHOLOGY }\end{array}$ \\
\hline Proponents & $\begin{array}{l}\text { Brussel } \\
\text { Liebert } \\
\text { Dietz } \\
\text { Milton } \\
\text { Montgomery } \\
\text { Britton } \\
\end{array}$ & $\begin{array}{l}\text { Depue } \\
\text { Ault } \\
\text { Ressler } \\
\text { Douglas } \\
\text { Burgess } \\
\text { Hazelwood } \\
\end{array}$ & $\begin{array}{l}\text { Canter } \\
\text { Heritage } \\
\text { larKin } \\
\text { Leyton }\end{array}$ \\
\hline \multirow[t]{3}{*}{ Methods } & $\begin{array}{l}\text { idiographic } \\
\text { casual consultants }\end{array}$ & $\begin{array}{l}\text { heuristic } \\
\text { law enforcement } \\
\text { personnel }\end{array}$ & $\begin{array}{ll}\text { nomothetic } \\
\text { - } & \text { university } \\
\text { researchers }\end{array}$ \\
\hline & $\begin{array}{l}\text { psychopathology. } \\
\text { personality theory \& } \\
\text { clinicalexperience }\end{array}$ & $\begin{array}{l}\text { behavioural sciences } \\
\& \text { databases }\end{array}$ & $\begin{array}{l}\text { psychology \& } \\
\text { empiricism }\end{array}$ \\
\hline & individualdiagnoses & $\begin{array}{l}\text { organised-disorganised } \\
\text { \& taxonomies }\end{array}$ & $\begin{array}{l}\text { five-factor\& } \\
\text { circle models }\end{array}$ \\
\hline
\end{tabular}




\section{Approaches to Profiling}

\section{J. Diagnostic Evaluations}

Profiling is viewed as a radical new technique
(Awt \& Reese 1980) but the approach has been with us for many years. Profiles described here as 'diagnostic evaluations' are the precursors of what today is termed criminal personality profiling. Essentially these encompass profiles done by individual psychiatrists and psychologists as needs arise or as their research interests demand. Unlike the more recent profiling approaches, diagnostic evaluations do not comprise a unified discipline nor follow any specifically prescribed methodology. Rather, they represent a cumulative body of work by individual mental health professionals who are consulted by law enforcement personnel to provide some insights to seemingly insoluable crimes (see Felman 1993). It is from the work of this loose collection of mental health workers that the term 'psychological profiling' was first derived.

Those conducting diagnostic evaluations seldom have extensive experience in law enforcement or related areas. Often their involvement in the construction of profiles is highly sporadic and consequendy they tend to lack sustained experience (Dietz 1985). The evaluations are generally based on clinical practice as well as being drawn from knowledge of personality theories and various psychological disorders. Nevertheless, the procedure is firmly grounded in the disciplines of psychology or psychiatry, and this individualised approach is slowly being more formalised so that replication is now possible (see Ressler \& Schactman 1992). The construction of profiles is achieved by diagnosing the probable psychopathology and! or personality type likely to have committed the crime. However, such a diagnosis can vary widely among different practitloners.

It is largely due to the diverse nature of these profiles and the variability of their accuracy levels that the characterisation of criminal personality profiling as 'hit and miss' (Goodwin 1978) or 'art not science' 01 orpagel 1982) has been generated. Yet, from within this diagnostic evaluation category come some of the most celebrated and seemingly accurate profiles. Indeed, many have such uncanny accuracy that they have yet to be rivalled in detail by practitioners of the other approaches (Wilson \& Seaman 1992). However,
Table 2

QuaHtative ratings of selected case study examples by the three approaches to profiling.

APPROACH ACCURATE SOLVED

\begin{tabular}{|c|c|c|c|}
\hline Mad Bomber & $\mathrm{DE}$ & yes & yes \\
\hline Boston Strangler & $\mathrm{DE}$ & yes & yes \\
\hline Great Lines Murders & $\mathrm{DE}$ & yes & yes \\
\hline Rydlemere Rapist & $\mathrm{DE}$ & yes & yes \\
\hline Mr Stinky & $\mathrm{DE}$ & yes & yes \\
\hline SatanistMurders & $\mathrm{DE}$ & yes & yes \\
\hline Granny Killer & $\mathrm{DE} / \mathrm{CSA}$ & partial & yes \\
\hline RachelNickell & DE/CSA & no & no \\
\hline Montana Murders & CSA & yes & yes \\
\hline Georgia Murders & CSA & no & yes \\
\hline USSlowa & CSA & no & doubt \\
\hline Vampire Killer & CSA & yes & yes \\
\hline Green River Killer & CSA & no & no \\
\hline Wayne Williams & CSA & yes & yes \\
\hline Trailside Killer & CSA & yes & yes \\
\hline Calabro Murder & CSA & yes & yes \\
\hline Soult Murder & CSA & yes & yes \\
\hline Devier Murder & CSA & yes & yes \\
\hline .22 Calibre Murders & CSA & yes & yes \\
\hline Fort Benning Killer & CSA & yes & yes \\
\hline Stocking Strangler & CSA & doubt & yes \\
\hline George Russell & CSA & yes & yes \\
\hline Prante Murder & CSA & yes & yes \\
\hline Vetter Killing & CSA & yes & yes \\
\hline Bell Murders & CSA & yes & yes \\
\hline ShawcrossMurders & CSA & partial & yes \\
\hline BTK Stranger & CSA & doubt & no \\
\hline Robert Hansen & CSA & assisted & yes \\
\hline 1-40Killer & CSA & assisted & yes \\
\hline RailwayRapist & IP & yes & yes \\
\hline BabbsRapes & IP & yes & yes \\
\hline Midlands Rapes & IP & yes & yes \\
\hline
\end{tabular}

NOTES

I. DE=Diagnostic Evaluations $; \mathrm{CSA}=$ Crime Scene Analysis:

$\mathrm{IP}=$ Investigative Psychology. these cases generally involve serial violent or sexual offenders but some isolated cases involve single victims.

2. In unsolved cases it is impossible to know whether the profile is accurate or not. but likewise in solved cases the profile may assist investigators even where it is partially or wholly inaccurate.

3. Increasingly, more than one profiler and more than one profiling type is being utilised on difficult cases.

it is also the case that the majority of profiles produced have been flawed.

Early recorded profiles of this type include Jack the Ripper (Rumbelow 1988), US President Woodrow Wilson (Tuchman 1967), and Adolf Hitler (Langer 1972). One of the most wellknown instances of a successful diagnostic evaluation was for the Mad Bomber of $\mathrm{New}$ York by 
psychiatrist, James Brussel. When apprehended, the Bomber's personality featUres coincided with the profile, including his preferred attire of 'double breasted suits with all the buttons done up' (Brussel 1968). Brussel was again consulted by police in 1962 to profile the Boston Strangler (Frank 1966). Although conflicting with the collective opinions of a score of other academics and psychiatrists requested to complete a similar task, Brussel accurately predicted characteristics which matched those of the later-confessed perpetrator (Brussel1968).

Similar profiles conducted more recently and in Australia include: the Rydlemere Rapist, the Mosman Granny Killer and Mr Stinky cases (see Simpson \& Harvey 1994; Kennedy \& Whittaker 1992). Table 2 shows some of these profiles and hints at their accuracy levels. The listing is dearly not exhaustive: but is used as a guide to comparing the three techniques. Such case studies act as excellent qualitative tools, but they are limited in the generalisations that can be applied. However, it would seem that the type of profiling that we call 'diagnostic evaluations' has some measure of success in terms of the profile outcome.

While no longer the sole source of offender profiles, diagnostic evaluations by individual psychiatrists, psychologists and criminologists continue to prevail. They appear to dominate in most countries in terms of prevalence and they provide the greatest accessibility in terms of the technique involved - one practitioner's knowledge of personality types and information about the crimes provided by police. However, this individualistic approach also prevents adequate comparative assessments of validity, utility and process, and the category of profiling now in the ascendancy is that of crime scene analysis.

\section{Crime Scene Analysis}

It was not until the 1970s, with the recognition of an increasing prevalence of bizarre and apparently random violent crime, that the FBI Behavioral Science Unit commenced research into offender profiling (Depue 1986; Pinizzotto 1984). Rather than following the lead of the mental health practitioners, the FBI adopted a utilitarian approach (Ressler, Douglas, Groth \& Burgess 1980). It stUdied crime scenes and imerviewed incarcerated offenders to construct typologies for certain offender categories. From the recognisable patterns in modus operandi
(Ressler, Burgess \& Douglas 1988), together with the baseline data of offender characteristics in conjunction with specific crime scene indicators, the FBI was able to create fairly well-defined offender templates.

The first research report, focusing on homicidal sexual sadists and lust murderers (Hazelwood \& Douglas 1980), provided qualitative analysis based on interview material. It was the first to document the organisedl disorganised dichotomy. Later this was refined to the organised non-social personality type and the disorganised asocial personality type (Megargee 1982). The organised type tends to be methodical and cunning, with little regard for social welfare, and often displays self-centred and irresponsible attitUdes or takes an immoral worldview (Holmes 1989; Geberth 1983). The disorganised type is usually more frenzied and bizarre in the commission of crimes and possibly suffers from psychosis (Holmes 1989; Geberth 1983).

A second major study by the FBI's BSU undertook both qualitative and quantitative analysis of 36 sexual murders and examined details of their combined 188 victims (Burgess et al 1986). This research showed that the organised/disorganised dichotomy was a continuum rather than tWo distinct categories (Ressler et al 1986). The concept of the 'mixed' offender arose from this study where the behavioural patterns contain features from either of the polar extremes of organised and disorganised styles (Ressler, Burgess \& Douglas 1988).

At the same time the FBI unit developed more systematic methods for crime scene analysis (Ressler, Burgess, Depue et al1985a \& b). Three prime questions emerged: what, why and who (Ressler \& Schactman 1992). Later came a more formalised model for developing the actUal criminal personality profiles (Douglas \& Burgess 1986) involving profiling inputs, decisionprocess models, feedback loops and crime assessment, from which the profile was created to then, theoretically at least, lead to investigation and apprehension.

The FBI unit, however, then retu.rned to explore the issue of motives - which had been abandoned in the belief that the main forms of crimes they were investigating were 'motiveless' ones. The net result was the publication of the FBI's Crimes Classification Manual (Ressler, Douglas, Burgess \& Burgess 1992). The Manual 
provides a formalised taxonomy of three primary classes of crime - homicide, sexual assault and arson - with sub-motive categorisations and lists of individual crime scene and typical offender characteristics for each of these sub-categories.

Despite the extent of the work done by the FBI, a number of criticisms can be made of this profiling type. First, it is believed that this approach has no real theoretical basis. It simply reduces human behaviour to a few observable parameters which lead to characteristics of the unknown offender. Second, the various descriptors used in the classification manual are not weighted or given any order of priority. The typologies include an extensive range of crime scene indicators and their associated heuristic inferences, but the formulation of profiles is still left to the subjective interpretation of the individual compiling them (see Kocsis 1995).

Finally, significant variations in modes and styles of crime can be observed across urban and rural locations (O'Connor \& Gray 1989) and the cultural implications in the commission of crime have long been studied in criminology. So the inherent disadvantage of the FBI's work, and in particular the Manual, is that it is drawn exclusively from United States data. No published

Australian studies exist which use or replicate any facet of the FBI criminal personality profiling research (see Kocsis 1996). There are, however, a small number of published articles in Australia which feature either descriptions or discussion of the criminal personality profiling technique (Callcott 1990; Fleming 1994; Hagen 1992; Pinto \& Wilson 1992; Ragg 1992; Wilson 1990) .

But what of the validity of this approach? Although some FBI studies have included the statistical procedures and findings of their research (Ressler et al 1986; Hazelwood \& Warren 1989a \& b) most of the published material does not. It is often claimed that FBI profiling predictions have a success rate 'in excess of 80 percent' (Canter \& Heritage 1990; Blackburn 1993) but the origin of this claim comes from a personal communication rather than any publicly documented study (Pinizzotto 1984). Inour own comparison in Table 2, it would seem that this approach is likewise successful, with some reservations.

Pinizzotto's study (1984) is one of the few to provide analysis of the FBI profiling techniques.
From 192 requests for offender profiles, 46\% were deemed to be of benefit in the investigation but only $17 \%$ were of assistance in the actual identification of the suspect (Pinizzotto 1984). However, a majority of respondents (77\%) claimed that the profiles did give a clearer focus for their investigation process - reinforcing its use as a tool rather than a crime-solving technique. Likewise in the Netherlands, most police report benefit from the use of profiles Qackson et al1993). Over 97\% reported that the profiles provided by the police intelligence service were useful. They did not, however, produce any tangible link to the actual resolution of the cnmes.

Later work (Pinizzotto \& Finkel 1990) compared profiles for homicide and sexual assault cases by professional profilers, detectives, psychologists and university students. Despite admitted defects in the case data, no significant differences were observed for the homicide case but the pro filers were superior to the other groups in creating an accurate profile in the sexual assault case (Pinizzotto \& Finkel 1990). What this study demonstrates is that profiling is most useful where there is a wealth of information and this is more likely to be found in a sexual assault case, where the victim (as eyewitness) is able to provide rich detail. The study also shows that profilers have an enhanced ability to extract the most information from the least detail. And other FBI research shows evidence of inter-rater reliability, where participants constructing profiles of sexual homicide crime scene classifications had agreement scores as high as 93\% (Ressler, Burgess, Depue et al1985a).

The FBI currently takes the lead in research on the development of criminal personality profiling as a formalised sub-discipline. Its emphasis tends to focus on crimes of interpersonal violence (generally homicide or sexual assault), although some independent work on profiles of arsonists has been conducted (Rider 1980; Kocsis 1996). This has been further refined in one study (I cove \& Estepp 1987) which combined motives, crime scene analysis and offender characteristics. Other research addresses specific crime categories or predictive models (Morrison 1995; Murphy \& Peters 1992; Kuznestov, Peirson \& Harry 1992).

While much research addresses the 'popularity' of profiling, there is still little that evaluates 
its validity and ethical dimensions. The value of the FBI's unit is otten measured by the amount of resources allocated to it and iis ever expanding nature (Van Zandt \& Ether 1994). The Association of Chief Police Officers in the United Kingdom, for example, now houses a specialised criminal personality profiling subdivision which parallels that of the FBI (Morley \& Clark 1993). Yet, another form of profiling emanating from Britain - what we have termed investigative psychology - now rivals the FBI approach.

\section{Investigative Psychology}

The most prominent of the individual proHlers, especially in the United Kingdom, is David Canter whose work has developed in parallel with that of the FBI since 1985. From within a university environment, Canter adapted psychological theories and experimental methods to assist law enforcement, first in the profiling of serial rapist, John Duffy (Canter 1988). His approach differs from that of the FBI in that he does not utilise practical police experience or interview data with a range of offenders,but rather has attempted to 'scientise' the techniques by drawing on social psychological theories, as well as criminology and forensic psychiatry (Wilson \& Soothill, 1996). Canter has postulated a number of concepts related to offender profiling but the most prominent are the five factor model and the circle theory (Canter 1994; Crace 1995).

The five factor model follows Canter's argument that models of offence behaviour are a necessary first step in establishing the relation of crime scene data to offender characteristics (Can ter \& Heritage 1990). Canter identified offence variables from victim statements in 66 sexual assaults. Using a non-metric form of multidimensional scaling, he identified a two dimensional, radex structUre in the data. In the centre of the space were the most frequent activities, such as vaginal intercourse, absence of reactions to the victim, use of impersonal language and surprise attack. This suggested that the use of a woman as the sexual object is at the core of most sexual assaults. Grouping the variables around the two dimensional space provided support for theories which variously relate sexual assaults to attempted intimacy, sexual gratification, aggression, impersonal inter- action and criminality. Canter postulates that different combinations of these factors exist in different offenders. When these factors are identified in the unknown crime, predictions of the offender can be derived (Canter 1989).

The circle theory arose from principles of environmental psychology. It creates formulae to allow for the prediction of an offender's residence based upon the spatial distribution of the serial offences. Critical to this theory are tWo hypothetical models of offender spatial behaviour (Canter 1993): the marauder mQdel, where spatial offence range has a causal relationship to the offender's home territory, and the commuter model, where no relationship exists. In Canter's study of 45 rapists, 39 demonstrated the marauder pattern. This produced an $87 \%$ accuracy rate when using the marauder model to predict base location (Canter 1993). The theory, however, is yet to be replicated (KocSis 1996).

A weakness of Canter's work is that to date it does not necessarily offer anything new, although contributions from the field of environmental psychology do provide new avenues to explore. What it does do is encouch known criminological or psychological principles in ways that can be useful to the crime investigator. It utilises the same factors as the FBI but places them firmly within psychological theory and methodology. It is also not yet clear how well Canter's theories (especially circle theory) will be adapted for use in the United States with its higher rate of serial crime, its greater penchant for mobility, and its more vast urban environment in many regions.

Canter's theories of criminal career, interpersonal coherence and implied relationship (Canter 1989) appear to be simply new terms for the FBI's categorisations of escaladon, victim/ offender risk and primary intent (Douglas, Ressler, Burgess \& Hartman 1986). However, Canter does differ with the FBI in that he sees little place for the organised-disorganised continuum because there is so much overlap that the distinctions become meaningless and there is little support from the data (Wilson \& Soothill 1996).

\section{Appraisals of Profiling}

By separating out the different forms of criminal personality profiling - diagnostic evaluations, crime scene analysis and investigative psychology 
- we are better able to assess their performance in terms of validity, utility and ethical dimensions. While direct evaluations of profiling are severely limited, a first step in comparing the three approaches has enabled us to isolate some commonalities and differences.

\section{Validity}

The popularity of profiling, as judged by the number of police forces who consult the FBI and other profilers, is seen otten as a measure of its success. Likewise its sustainability, popularity and development into other areas of police work are also seen as positive measures (Wilson \& Soothill 1996). Indeed, profiling has burgeoned. The FBI's BSU now incorporates a number of other centres such as the National Centre for the Analysis of Violent Crime; in the United Kingdom the Association of Chief Police Officers contains a specialised offender profiling subdivision (Morley \& Clark 1993); and in Australia the National Police Research Unit conducted a feasibility study for the establishment of a violent crimes database (VICAP) and profiling service. Senior detectives in Australia responded positively to a survey on establishing a proflling facility here (Beck, O'Sullivan \& Ogilvie 1989), and in 1995 such a facility was established at the Australian Bureau of Criminal Intelligence in Canberra.

Yet as we have noted already, there are few publicly available evaluation studies that address the validity of anyone or all of the three profiling types described. The lack of empirical evaluations is either because the studies have yet to be done and published, or because the FBI and others are professionally guarded about releasing results of actuarial evidence. However, our own tentative analysis shows a preponderance of known successes over failures, which does augur well for the validity of the techniques.

The crucial question that needs to be asked is what profiling is meant to achieve; only by delimiting the variables involved can we hope to be able to measure its success or failure empirically. Some of these aspects include (see Wilson \& Soothill 1996):

- as an investigative aid where there are few leads;

- determining' one-off from serial offences;
- giving direction to an investigation that has no new leads;

- $\quad$ offering psychological advice for interviewing techniques;

offering psychological advice for witnesses or juries at trial;

- creating systematised computer records of unsolved serious crimes on a national basis;

encouraging communication betWeen jurisdictions on unsolved serious crimes;

providing feedback for investigative procedures;

- providing feedback for forensic evidence collection, sampling etc;

providing input to psychological and criminological theories; and

- assisting with corroborating evidence once a suspect has been identified.

Until these potential benefits of profiling have been isolated and then rigorously tested, the best we can say is that some profiles are uncannily accurate but these are somewhat rare cases. The majority of profiles, across all three approach categories, are mildly to severely flawed, but may nevertheless provide some benefit to investigatOrs in the absence of other assistance.

\section{Utility}

As noted at the outset, profiling is useful for crimes where there is some evidence of psychopathology in the offenders, such as lust killings or those where extensive mutilation is present (Holmes 1989; Wilson 1986). As with sexual assault cases, this is generally because there is more evidence at the crime scene from which to extract information. In order to eviscerate a body or otherwise engage in post-mortem mutilation, the offender needs to spend some time in the crime setting. Conversely, profIling to date has been found to be of little use in most forms of property and drug-related crimes Oackson et al1993; Lynch \& Dale 1994). Many property crimes take only a few minutes to execute, offenders are often disguised and wear gloves, flee immediately to avoid apprehension and, therefore, have little contact with the crime scene. In drug crimes, the drug-related behaviour may mask the true underlying personality characteristics of the offender thereby making inferences from crime scene analysis less relevant. 
Likewise, profiling is most useful in serial offences where there are multiple crime scenes from which to extrapolate and compare data. Fortunately, such stranger killings are rare for in most homicide cases the offenders are known to the victims or there are eyewitnesses present. Of course this is also one of the strengths of profiling

- as a tool in those cases where there are no leads. Yet, in some ways profiling merely extends traditional policing methods. For example, in the Netherlands study, in one out of six cases where a profile was compiled, the police had already uncovered some of the characteristics defined in the profile Oackson et alI993).

Where profiles also can be used successfully is in providing interviewing skills or approaches for detectives to use once a potential suspect has been apprehended (Gudjonsson 1992). This can have important implications for the case when it goes to trial. Also in this vein, profiles can offer useful strategies for prosecutors to pursue, through personality assessments of the accused, witnesses or indeed juries under voir dire in the United States, for example.

With respect to expert testimony, 'there does not currently appear to be support for profiles as a whole, to constitute evidence' (Lucy 1995, p 18). It seems that they have been utilised in United States' courtrooms, generally to rebut insanity pleas, but it may be that their use will extend in the future (Lucy 1995). A profile can be used as corroborative evidence or circumstantial evidence and need not be proved beyond reasonable doubt. It can also provide character evidence although this is a problem where it infers criminality, because like actuarial evidence it relies on probability and raises questions about standard of proof. A profile can be introduced if it satisfies the Frye test. As with expert evidence in general, the profile must include material that could not be within the knowledge of the judgel magistrate and, for it to be admitted, expert knowledge needs to be demonstrated in that it must significantly assist the case and the expert must show qualifications to address the topic (Lucy 1995).

As to the Utility of profiling for the resolution of crimes, conclusions are equally ambiguous. Profiling experts openly state that offender profiles have never meant to lead exclusively to the apprehension of offenders but are merely another investigative aid (Ressler \& Schactman
1992). Whether they have utility or not, the increase in their use is a clear indication of their increased perceived utility (Canter 1994). It is also clear that police personnel are now convinced (despite some earlier widespread misgivings in Australia) that profiling is of use to them. What is less clear is how ethical guidelines will develop to control the potential misuse of profiles.

\section{Ethics}

Several recent cases in the United Kingdom show how profiles can be misunderstood and then misused by law enforcement as a means of entrapment of suspects. Wilson and Soothill (1996, p12) raise important questions about the 'appropriateness or value of the procedure' in their critique of the problematic use of psychological profiling in the case of Colin Stagg. In this case a profile was developed by Paul Britton that almost perfectly described Colin Stagg. However, in order to secure sufficient evidence to convict, the police with the help of Britton, acted as agent provocateurs by having a female officer engage in suggestive correspondence with him (Wilson \& SoothillI996).

However, it would seem that the problems of profiling in this instance relate more to professional competence rather than ethical features of the technique itself. There should be an onus on experts to point to the limitations of profiling (as should be the case with predictions of dangerousness, for example). The Stagg case should not be used to condemn profiling outright, even though psychological assistance was given in how to communicate with the alleged suspect. It is entrapment that rightly should be condemned in this situation and possibly, as suggested by Canter, Britton's lack of scientific approach (Wilson \& Soothilli996).

The 'Granny Killer' case in Australia where six elderly women were killed in Sydney - also brought profiling into some disrepute and raised questions about the ethics of engaging in the 'art' of drawing up profiles. In this case several profiles contained accurate detail of the possible offender but all failed on the category of age (late teens or early 20s was specified, whereas the perpetrator was in his late 50s). The perpetrator was eventually apprehended but the ethical concerns about the dangers of erroneous profiles were clearly highlighted. 


\section{Conclusions}

However, ethical criticisms of profiling are very much tied up with criticisms of the technique's utility and validity. Not only is the technique limited generally to serial offences and to fairly bizarre murders, it is reductive rather than productive in that it narrows the field of suspects but is incapable of specifically identifying one. In addition, it creates a wealth of information but may be incorrect on key characteristics so that investigators end up 'not seeing the wood for the trees' or it can create stereotypes of offenders which may lead to wrongful arrests. Finally, it relies on data from convicted felons rather than those who are never caught and so the data may be seriously flawed (see Wilson \& Soothill1996).

These arguments otten are packaged together and given an ethical dimension by referring to the Stagg case and other apparent failures. We would argue, however, that profiling is no more unethical than any other investigative technique. It is how profiling (or any other technique) is used in any given case, which is important, rather than an overall assessment of its 'ethics' per se. However, as an investigative technique for assisting in the solution of serial crimes it offers promise and insight otten not available through traditional investigative avenues.

\section{References}

Ault, RL. \& Reese, J.T. (1980) 'A psychological assessment of crime profiling', FBI Law Enforc(ment Bulletin, 49(3), 22-25.

Beck, J.P., O'Sullivan, B.J. \& Ogilvie, A.B. (1989) An Australian Violmt Criminal Appr(hmsion Programm(: A hasibility Study, National Police Research Unit, Adelaide.

Blackburn, R. (1993) Th( Psychology of Criminal Conduct, John Wiley \& Sons, Liverpool.

Brussel, J. (1968) Cas(book of a Criminal Psychiatrist, Bernard Geis, New York.

Burgess, A.W., Hartman, C.R., Ressler, RK., Douglas J.E. \& McCormack, A. (1986) 'Sexual homicide: a motivational model', Journal of Int $r p$ (rsonal Vioknc(, 1(3), 251-72.

Callcott, G. (1990) 'Criminal profiles', Po/iC( Lift, October,8.

Canter, D. (1988) 'To catch a rapist', N(w Socilty, 14-15.

Canter, D. (1989) 'Offender profiles', Th( Psychologist, 2(1), 12-16.
Canter, D. (1993) 'The environmental range of serial rapists', Journal of Environmental Psychology, 13, 63-69.

Canter, D. (1994) Criminal ShaMws, Harper Collins, London.

Canter, D. \& Heritage, R. (1990) 'A multivariate model of sexual offence behaviour: developments in offender profiling', Journal of Forensic Psychiatry, 1(2), 185-212.

Crace, J. (1995) 'Inside the criminal mind', $N(w$ Stat(sman and Socilty, 17 February, 29-30.

Davies, A. (1994) 'Editorial: offender profiling', M(dicin(, Scienc) and th( Law, 34(3), 185-86.

Davis, J.A. (1994) 'Criminal investigative analysis: selected readings in criminal and psychological profiling', unpublished paper, San Diego CA.

Depue, RL. (1986) 'An American response to an era of violence', FBI Law Enforammt Bul/(tin, 55(12), 1-8.

Dietz, P.E. (1985) 'Sex offender profiling by the FBI: a preliminary conceptual model', in Clinical Criminology, eds M.H. Ben-Aeon, S.J. Hucher \& C.D. Webster, M \& M Graphics, Toronto, 207-19.

Douglas, J.E. \& Burgess, A.E. (1986) 'Criminal profiling: a viable investigative tool against violent crime', FBI Law Enforc(ment Bul/(tin, 55(12), 9-13.

Douglas, J.E. \& Munn, C. (1992) 'Violent crime scene analysis: modus operandi, signature and staging', FBI Law Enforc(ment Bulktin, 61(2), 1-10.

Douglas, J.E. \& Olshaker, M. (1996) Mindhunt $r$, Heinemann, London.

Douglas, J.E., Ressler, R.K., Burgess A.W. \& Hartman, C.R. (1986) 'Criminal profiling from crime scene analysis', B(havioural Scienas and the Law, 4(4), 401-21.

Felman, P. (1993) Th( PsychologyofCrim(, Cambridge University Press, Cambridge.

Fisher, A.J. (1993) T(chniqu(s of Crim( Scm( Inv(stigation, 5th edition, Elsevier, New York.

Fleming, L. (1994) 'Serial murder', Australian Polic( Journal, 48(6), 59-72.

Frank, G. (1966) Th( Boston Strangl(r, Signet, New York.

Geberth, V.J. (1981) 'Psychological profiling', Law and Order, 46-52.

Geberth, V.J. (1983) Practical Homicide Inv(stigation: Tactics, Proadur(s and Formsic T(chniqu(s, Elsevier, New York.

Goodwin, J. (1978) Murder USA: Th( Ways W( Kill Each Oth(r, Ballantine, New York. 
Gudjonsson, G. (1992) Th PsychologyofInt rrogatiom. Confissiom and T stimony, John Wiley \& Sons, London.

Hagen, M. (1992) 'Special issues in serial homicide', in Homicide: Patt rns, Prevention and Control, eds $\mathrm{H}$. Strang \& S.A. Gerull, Australian Institute of Criminology, Canberra, 135-37.

Hazelwood, R.R., Dietz, P.E. \& Burgess, A.W. (1982) 'Sexual fatalities: behavioural reconstruction in equivocal cases', Journal of Forensic Scienas, 127(4), 763-73.

Hazelwood, R.R. \& Douglas, J.E. (1980) 'The lust murderer', FBI Law Enforc ment Bull tin, 49(3), 18-22.

Hazelwood, R.R. \& Warren, J. (1989a) 'The serial rapist, his characteristics and victims, part 1', FBI Law Enforc ment Bulktin, 58(1), 11-17.

Hazelwood, R.R. \& Warren, J. (1989b) 'The serial rapist, his characteristics and victims, part II', FBI Law Enforcem nt Bulktin, 58(2), 19-25.

Holmes, R.M. (1989) Profiling Violent Crim $\sim$ : An Inv stigativ Tool, Sage, Beverly Hills.

Icove, D.J. \& Estepp, M.H. (1987) 'Motive based offender profiles of arson and fire related crimes', FBI Law Enforc ment Bull tin, 56(9), 17-23.

Jackson, J., Van Hoppen, P.J. \& Hebrink, J. (1993) Do s th S rvic Mat th N ds? Netherlands Institute for the Study of Criminality, Amsterdam.

Jeffers, H.P. (1992) Profiks in Evil, Warner Brothers, London.

Kennedy, L. \& Whittaker, M. (1992) Granny Kill r: Th Story ofJohn Glov r, Harper Collins, Sydney.

Kocsis, R. (1995) 'Offender personality profiling: a viable investigative supplement', unpublished paper, Bond University.

Kocsis, R. (1996) 'Criminal personality profiling: featUres of arson in Australia', MA Criminology Thesis, Bond University.

Kuznestov, A., Peirson, T.A. \& Harry, B. (1992) 'Victim age as a basis for profiling sex offenders', Federal Probation, 56, 34-38.

Langer, W. (1972) Th Mind of Adolf Hitkr: Th S cr t Wartim R port, Basic Books, N ew York.

Lucy, J. (1995) 'Offender profiling: what is it and what does it have to offer?' unpublished paper, School of Law, Flinders University.

Lynch, I. \& Dale, A (1994) 'Profiling the burglars', Polic R vi w, 102, 18-19.

McCann. J.T. (1992) 'Criminal personality profiling in the investigation of violent crime: recent advances and future directions', B havioral Scienw and th Law, 10,475-81.

Megargee, E.!. (1982) 'Psychological determinants and correlates of criminal violence', in Criminal
Violenc , eds M.E. Wolfgang \& N.A. Weiner, Sage, Beverly Hills.

Morley, M. \& Clark, S. (1993) Murd r in Mind, Boxtree, London.

Morrison, R. (1995) 'Profiling aberrant sexual behavior: abnormal patterns can predict futUre crimes', Law and Order,43(3), 100-102.

Murphy, W.O. \& Peters, J.M. (1992) 'Profiling child sexual abusers: psychological considerations', CriminalJustic and B havior, 19(1),24-37.

Nowikowski, F. (1995) 'Psychological offender profiling: an overview', Th Criminologist, 19(4), 255-73.

O'Connor, M. \& Gray, D. (1989) Crim in a Rural Community, Federation Press, Sydney.

Pinizzotto, AJ. (1984) 'Forensic psychology: criminal personality profiling', Journal of Polic $\sim$ Scienc $\sim$ and Administration, 12(1),32-40.

Pinizzotto, A.J. \& Finkel, N.J. (1990) 'Criminal personality profiling: an outcome and process study', La'w and Human B havior, 14(3), 215-33.

Pinto, S. \& Wilson, P. (1992) 'Serial murder', in Issues in Crim , Morality and Justic , ed P. Wilson, Australian Institute of Criminology, Canberra, 157-73.

Ragg, M. (1992) 'Killers beware', Th Bulktin, 11,2.

Rayment, M. (1995) 'Inside the mind of a criminal', NSW Polic N ws, 75, 15-18.

Ressler, R.K., Burgess, A.W., Depue, R.L., Douglas, J.E. \& Hazelwood, R.R. (1985a) 'Classifying sexual homicide crime scenes', FBI Law Enforcement Bulktin, 54(8), 12-18.

Ressler, R.K., Burgess, A.W., Depue, R.L., Douglas, J.E. \& Hazelwood, R.R (1985b) 'Crime scene and profile characteristics of organised and disorganised murderers', FBI Law Enforc ment Bulktin, 54(8), 18-26.

Ressler, R.K., Burgess, AW. \& Douglas, J.E. (1988) Sexual Homicide: Patt rns and Motiv s, Lexington, New York.

Ressler, R.K., Burgess, AW., Douglas, J.E., Hartman, C.R. \& D'Agnostino, R.B. (1986) 'Sexual killers and their victims: identifying patterns through crime scene analysis', Journal of Int rp rsonal Vioknce, 1,288-308.

Ressler, R.K., Douglas, J.E., Burgess, A.W. \& Burgess, AG. (1992) Crim Classification Manual, Simon \& Schuster, London.

Ressler, R.K., Douglas, J.E., Groth, A.N. \& Burgess, A.W. (1980) 'Offender profiles: a multidisciplinary approach', FBI Law Enforc ment Bull tin, 49(9), 16-20.

Ressler, RK. \& Schactman, R (1992) Who v r Fights Momt rs, Simon \& Schuster, London. 
Rider, A.a. (1980) 'The firesetter: a psychological profile, part II', FBI Law Enforcemmt Bulletin, 49(7), 7-17.

Rossi, D. (1982) 'Crime scene behavioral analysis: another tool for the law enforcement investigator', Police Chief, 152-55.

Rumbelow, D. (1988) The Complete Jack the Ripper, Penguin, London.

Simpson, 1. \& Harvey, S. (1994) The Killer Next Door: Death in an Australian Suburb, Random House, Sydney.

Slahor, S. (1991) 'Making profiling work', Law and Order, 39(4), 76-77.

Smith, C. (1993) 'Psychological offender profiling', The Criminologist, 17(4),244-45.

Tuchman, B. (1967) 'Can history use Freud? The case of Woodrow Wilson', The Atlantic Monthly, 3, 39-44.

Turco, R.N. (1990) 'Psychological profiling', International Journal of Offender Therapy and Comparative Criminology, 34(2), 147-54.
Vandiver, J. (1982) 'Crime profiling shows promise', Law and Order,30(10), 33-78.

Van Zandt, C.R. \& Ether, S.E. (1994) 'The real "Silence of the Lambs"', Police Chief, 11(4), 45-52.

Vorpagel, R.E. (1982) 'Painting psychological profiles: charlatanism, coincidence, charisma or new science', Police Chief,3(8), 156-59.

Walter, R. (1987) 'Sex killers: their actions and reactions', Australian Police Journal, 92-97.

Wilson, C. \& Seaman, D. (1992) The Serial Killers, Cox and Wyman, London.

Wilson, P. (1986) 'Serial and lust murder: questions on police management and response', Australian PoliceJournal, November, 2-8.

Wilson, P. (1990) 'Sex and crime', Australian Journal of Forensic Sciences, 22(3), 93-100.

Wilson, P. \& SoothiU, K. (1996) 'Psychological profiling: red, green or amber?' The Police Journal, January, 12-20. 